\title{
CORDEL E RELIGIOSIDADE: A FIGURA DO PROTESTANTE NA OBRA DA PRIMEIRA GERAÇÃO DE CORDELISTAS
}

\section{Micheline Reinaux de Vasconcelos ${ }^{1}$}

Ao longo da última década do século XIX e da primeira do século XX, no estado da Paraíba, começam a ser produzidos pequenos folhetos que davam forma impressa a composições orais, que nós conhecemos como "literatura de cordel". No Brasil, porém, esta expressão só se tornou usual em meados do século $\mathrm{XX}$, quando estudiosos usaram-na para denominarem a literatura popular, pois, até então, os autores chamavam às suas próprias obras de folhetos².

Considerado o autor fundante da literatura de cordel do país, Leandro Gomes de Barros, nascido em Pombal (Paraíba) em $1868^{3}$, viveu na regiáo considerada berço da poesia popular nordestina, a região paraibana do Vale do Teixeira. Ele escrevia $e$ imprimia seus folhetos já nos anos 1890, mas passou a viver unicamente da venda dos cordéis que produzia apenas quando se tornou morador do Recife, a partir de $1909^{4}$.

Outro dos nossos cordelistas pesquisados, João Melchiades Ferreira da Silva, intitulava-se o "cantor da Borborema"; nasceu em Bananeiras, na Paraíba. Filho de família de pequenos proprietários, aprendeu a ler e escrever com seu avô, exseminarista. Entrou para o exército, tendo participado da guerra de Canudos e da do Acre; terminou por se aposentar como sargento devido a problemas de saúde. Mudou-se para João Pessoa, onde passou a viver da aposentadoria, da venda de seus folhetos e das suas cantorias ${ }^{5}$.

Neste artigo, pretendemos analisar a figura do protestante tal como ela é caracterizada pela primeira geração de cordelistas. À época em que estes autores estavam produzindo seus folhetos, representantes das principais denominações protestantes já se encontravam no Brasil, promovendo atividades de proselitismo junto à população há algumas décadas.

Antes do envio de missionários ao Brasil, inicia-se, logo após a abertura dos portos, a distribuição de Bíblias pelas sociedades bíblicas inglesa e norte-americana. $\mathrm{O}$ primeiro grupo protestante de caráter proselitista a vir ao Brasil compunha-se de membros da igreja congregacional. O início do trabalho congregacional no Brasil

${ }^{1}$ Doutora em História pela Ponticífia Universidade Católica de São Paulo. Tutora no Centro de Educação a Distância do Polo Recife da Universidade Anhanguera de São Paulo. Vice-Coordenadora do Grupo de Trabalho Histórico Ecumênico Organizado - GTHEO, onde coordena a pesquisa sobre a catalogação e digitalização de fontes de instituições religiosas no Recife. E-Mail: $<$ mrdevasconcelos@gmail.com>.

${ }^{2}$ SLATER, Candece. A vida no barbante: a literatura de cordel no Brasil. Tradução de Octavio Alves Velho. Rio de Janeiro: Civilização Brasileira, 1984, p. XIII.

${ }^{3}$ CURRAN, Mark. J. A literatura de cordel. Recife: UFPE, 1973, p. 32.

${ }^{4}$ MEYER, Marlyse. Autores de cordel. São Paulo: Abril Educação, 1980, p. 08-09.

${ }^{5}$ TERRA, Ruth Brito Lemos. Memória de lutas: primórdios da literatura de folhetos do Nordeste (18901930). Dissertação (Mestrado em Linguística e Línguas Orientais). Universidade de São Paulo. São Paulo, 1978, p. 44-45. 
ocorreu em 1855, quando o casal Robert Reid Kalley e Sarah Poulon Kalley chegou ao Rio de Janeiro. As denominações presbiteriana e batista também virão se estabelecer no Brasil. A Junta de Missões Estrangeiras da Igreja Presbiteriana do Norte dos Estados Unidos envia em 1859 seu primeiro missionário ao Brasil; pouco depois, Ashbel Green Simonton começa seu trabalho como capelão. Por sua vez, os primeiros missionários batistas a atuar no país foram o casal Willian Buck Bagby $e$ Anne Luther Bagby, que chegam ao país somente em 1881. Assim como os metodistas e episcopais, de modo que, no final do século XIX, as principais denominações protestantes já se encontravam no território nacional.

A atuação destes missionários não passou despercebida por Gustavo Barroso, autor contemporâneo, que relatou suas impressões da penetração dos protestantes pelo Nordeste:

De certo tempo a esta parte, missionarios de egrejas $e$ confrarias protestantes norte-americanas têm fundado capellas e estabelecido nucleos religiosos nas capitaes dos Estados de Nordeste. Esses pastores, satisfeitos com o bom resultado obtido ahi com a predica do seu credo religioso, vão enviando outros ao interior, afim de procurarem novas ovelhas para seu rebanho. Como é de suppôr, topam no caminho a resistencia dos sacerdotes catholicos e do próprio povo; mas, apezar disso, vão adquirindo proselytos, embora em pequeno numero, e continuam tenazmente sua catechese. ${ }^{6}$

Deste modo, foi com estas figuras - missionários e neófitos - que os cordelistas devem ter tido contato, ouvindo suas pregações ou, pelo menos, lendo os impressos que aqueles distribuíam. A partir da nossa pesquisa sobre a caracterização do protestante por estes cordelistas, quatro aspectos serão destacados: a presença da Bíblia, o debate em torno do culto a Maria, as discussóes sobre o uso de imagens sacras e, por fim, a descrição física dos indivíduos adeptos do cristianismo reformado.

\section{O livro do nova-seita}

Uma das formas populares de referir-se àqueles que professavam algumas das denominações protestantes é a expressão nova seita, como esclarece Barroso:

O protestantismo é chamado no sertão nova seita e os sertanejos que o abraçam são ridicularisados. Esses pequenos choques de idéias religiosas já estão documentados na poesia satyrica popular, embora com manifesta parcialidade contra os protestantes. ${ }^{7}$

\footnotetext{
${ }^{6}$ BARROSO, Gustavo. Ao som da viola. Rio de Janeiro: Leite Ribeiro, 1921, p. 506.

${ }^{7}$ BARROSO, Ao som da viola, p. 506.
} 
A expressão aparece em diversos folhetos de cordel, os quais passamos a citar em seguida, destacando as características que se atribuem aos "nova seita". A partir das estrofes de alguns cordéis, nota-se a presença da Bíblia como uma referência característica da ação dos protestantes. É o que se percebe no cordel $O$ diabo confessando um nova seita, no qual as personagens são as do título:

\author{
E alli chegando um negro, \\ Trazendo um livro na mão \\ Interrogando ao barbado; \\ O que deseja irmão? \\ Disse o velho meu padastro \\ Me ouça de confissão. ${ }^{8}$
}

Como se vê, o diabo, apresentado como o "padrasto" (em oposição ao Deus Pai) dos nova-seitas, é caracterizado, entre outros aspectos, por portar "um livro na mão", provavelmente uma Bíblia. Neste folheto não fica claro se o poeta mostra um relativo desconhecimento das práticas dos protestantes ou se usa de ironia, uma vez que descreve um nova-seita confessando-se, norma que não se observa nas denominações protestantes.

Note-se, além disso, que a frase "Trazendo um livro na mão", relaciona-se a um aspecto recorrente nos cordéis: a caracterização dos protestantes com portadores de uma Bíblia.

Em A Alma de uma Sogra, de autoria do mesmo cordelista, um velho tabelião descreve as características de cada uma das cinco sogras que teve. Para caracterizar uma delas, os versos dizem assim:

Depois de morta tres annos

Onde sepultaram ella

Nasceu em cima da cova

Tres toceiras de mazella

Um livro de nova seita

Achou-se no caixão della. ${ }^{9}$

Ou seja, o que indicava que a mesma era "nova seita" é a posse de uma Bíblia.

$\mathrm{O}$ destaque conferido às Escrituras pelos cristãos reformados relaciona-se com os graus diversos de importância da cultura escrita para cada uma das vertentes cristãs. A relação entre protestantismo e leitura tornou-se tão peculiar que no decurso de algumas gerações, o abismo entre protestantes e católicos havia se ampliado a ponto de gerar culturas literárias e modos de vida contrastantes ${ }^{10}$.

\footnotetext{
${ }^{8}$ BARROS, Leandro Gomes de. O diabo confessando um nova seita. Recife: Imprensa Industrial, [s/d.], p. 2. Instituto de Estudos Brasileiros - IEB/USP, Arquivo. Fundo Villa Lobos, nº 09.

${ }^{9}$ BARROS, Leandro Gomes de. A alma de uma sogra. S/l: s/n, s/d, p. 8.

${ }^{10}$ EISENSTEIN, Elizabeth L. A Revolução da Cultura Imprensa. Os primórdios da Europa Moderna. Trad. São Paulo: Ática, 1998, p. 174.
} 
Note-se, porém, que há indício diverso da presença da leitura de trechos da Bíblia, juntamente com outros de teor religioso, entre os nordestinos ainda no século XIX. Trata-se de uma versão impressa, resumida e em linguagem popular chamada Missão Abreviada que, tendo sido introduzida em Portugal, circulou no Nordeste desde a segunda metade do Dezenove ${ }^{11}$. De acordo com Câmara Cascudo, edições da Missão Abreviada, cujo autor era o padre Manuel Couto, tinham tiragens de 12.000 volumes. Da Missão provinham recursos de orações, explicações de fácil teologia, resposta às curiosidades irreverentes, regimes de jejuns, dietas sagradas, abstinências, catecismo, regras morais ${ }^{12}$.

Estas publicações eram distribuídas pela Santa Missão, levada a cabo pelos lazaristas franceses e, principalmente, pelos frades capuchinhos italianos, no século $\mathrm{XIX}$, os quais, além de pregarem e ministrarem os sacramentos, coordenavam trabalhos coletivos de "obras públicas", isto é, de benfeitorias para uso da população, tais como pontes, estradas, açudes, etc ${ }^{13}$. Estas missões tinham por fim afervoramento religioso, ocasião de conversões, e regularização de vida, reconciliação de ódios, afastamento dos abusos e superstições, volta aos sacramentos ${ }^{14}$.

Os capuchinhos e suas missões no interior do Nordeste, especialmente entre Alagoas e Pernambuco, foram reintroduzidos nos anos 1840, com o fim de pacificar indígenas e camponeses sublevados. Seus membros eram recrutados no sul da península itálica, dentre os camponeses, treinados em Roma pela Propaganda Fide a respeito das peculiaridades da língua e da sociedade brasileira. Desta forma, os capuchinhos e outras ordens mendicantes, especialmente capacitados para o convívio com os "rústicos" e "simples" camponeses - aos quais falavam na sua própria e rude língua e traduziam a "palaura de Deus" 15 contribuíram para a construção de [uma] cultura religiosa popular oralmente transmitida no sertão nordestino que guarda forte relação com tradições católicas ${ }^{16}$.

É provável, igualmente, que a imprensa tenha sido outra forma pela qual os cordelistas tenham tido contato com as disputas entre católicos e protestantes. No período do qual tratamos, as polêmicas religiosas se deram com maior evidência na imprensa secular, proporcionando um momento também marcado pelo surgimento de vários jornais católicos e protestantes ${ }^{17}$. Mas vale ressaltar que essas polêmicas já

11 ANTONACCI, Maria Antonieta. "Tradições de oralidade, escritura e iconografia na literatura de folhetos: nordeste do Brasil, 1890/1940", Projeto História. São Paulo, PUC-SP, n. 22, jun. 2001, p. 117.

${ }^{12}$ CASCUDO, Luís da Câmara, Vaqueiros e catadores. São Paulo: Itatiaia; EDUSP, 1984, p. 131.

${ }^{13}$ HOORNAERT, Eduardo. O cristianismo moreno do Brasil. Petrópolis: Vozes, 1991, p. 50, p. 52.

${ }^{14}$ FRAGOSO, Hugo. "A igreja-instituição". In: BEOZZO, José Oscar (coord.). História da Igreja no Brasil. Petrópolis: Vozes, 1989, p. 209.

${ }^{15}$ PALACIOS, Guillermo. "Campesinato e Escravidão: uma proposta de periodização para a história dos cultivadores pobres livres no Nordeste Oriental do Brasil: c. 1700-1875". Dados - Revista de Ciências Sociais, Rio de Janeiro, vol. 30, n. 3, 1987, p. 344-345.

${ }^{16}$ BRITO, Gilmário M. Cultura e linguagem em folhetos religiosos do Nordeste. Tese (Doutorado em História). Pontifica Universidade Católica de São Paulo. São Paulo, 2001, p. 170.

${ }^{17}$ Ver, por exemplo: "EM AÇÃO!". A Provincia. Recife, Columna Religiosa, n. 221, 28 set. 1902, ano XXV, p. 01. FREI CELESTINO. "Combate ao protestantismo. Carta Aberta". A Provincia. Recife, n. 221, 28 set. 1902, ano XXV, n. 01. 
estavam presentes no período Imperial, como resultados de embates com o ultramontanismo católico.

Ao incentivar a leitura da Bíblia por parte dos fiéis sem a intermediação eclesiástica, os missionários reformados estariam estimulando a livre interpretação. Esta, por sua vez, seria ainda mais perigosa, segundo as autoridades católicas, se feita sobre um texto dito "adulterado" ou "truncado". A referência constante pela prédica oficial católica à 'adulteração' sofrida pela Bîblia nas mãos dos protestantes diz respeito à ausência dos sete livros do Velho Testamento, considerados apócrifos pelos protestantes: Baruc, dois livros de Macabeus, Judite, Tobias, Eclesiásticos e Sabedoria.

Tomemos, ainda sobre este aspecto, duas estrofes de outro cordel de Leandro Gomes de Barros, chamado $O$ debate do ministro nova-seita com o urubu ${ }^{18}$. Este folheto inclui-se no gênero "peleja e discussão". A peleja reproduz disputas poéticas entre cantadores, sendo a maior parte imaginada pelo cordelista. A "discussão" é uma paródia da peleja, onde reproduz um debate entre duas partes com diferentes opiniões ou visões de mundo ${ }^{19}$. A disputa em torno da leitura da Bíblia pelos protestantes ganha ênfase na discussão entre as personagens:

Então, disse o nova-seita:

Urubú, estás enganado,

Eu estudei toda a Bíblia,

Estou nella baseado.

Perguntou-lhe o urubú:

Quem? Você? Está atrazado.

Então, disse o nova-seita:

A Biblia tenho estudado,

Vi o que Deus escreveu,

Sou fiel a seu mandado.

Respondeu o urubú:

Você está excommungado!

É pertinente notar-se como as falas do urubu indicam uma fidelidade à tradição, enquanto o "nova-seita" insiste na leitura da Bíblia como fonte exclusiva de sua crença e de sua prédica. Uma das balizas do movimento da reforma protestante foi a sola Scriptura, ou seja, a persistência pela autoridade da Bíblia em detrimento da tradição ${ }^{20}$. No dizer de Martin Dreher, o séc. XVI é o século da vitória da palaura sobre a imagem e sobre o gesto ${ }^{21}$. Fica claro no trecho que, diante da fé resoluta do urubu,

\footnotetext{
${ }^{18}$ Apud BARROSO, Ao som da viola, p. 506-13.

${ }^{19}$ MEYER, Marlise. Autores de cordel. Seleção de textos e estudo crítico por M. Meyer. São Paulo: Abril Educação, 1980, p. 98.

${ }^{20}$ PELIKAN, Jaroslav. Maria através dos séculos: seu papel na história da cultura. São Paulo: Companhia das Letras, 2000, p. 210.

${ }^{21}$ DREHER, Martin. A crise e a renovação da igreja no período da Reforma. São Leopoldo: Sinodal, 1996, p. 55.
} 
o ministro aponta que a fonte de sua crença é única e exclusivamente a leitura da Bíblia.

\section{A polêmica sobre o culto de Maria}

Dentre os folhetos protestantes divulgados por missionários, encontra-se a tradução do polêmico panfleto "O retrato de Maria como ela é no céu". Tal panfleto contradizia o destaque conferido a Maria pelos católicos, fazendo parte da ênfase dada pelos protestantes a este tema. Assim, supomos, consiste numa das formas pelas quais a população tomou conhecimento do debate entre católicos e protestante em torno desta questão.

Na obra 107 invocações da virgem Maria, a autora Nilza Megale nos informa que a imagem de nossa senhora da Conceição foi introduzida no Brasil pelos frades franciscanos e que atualmente há 375 paróquias a ela dedicadas. Mas antes disso a imagem já estava relacionada ao conflito português contra a dominação filipina e à Restauração Portuguesa em 1640. Em uma das naus de Pedro Álvares Cabral havia uma imagem de nossa senhora da Conceição.

Ainda segundo a autora a primeira igreja brasileira ao norte do Rio São Francisco consagrada a essa invocação ficava na antiga vila de Itamaracá, hoje no território do estado de Pernambuco ${ }^{22}$. Percebe-se, assim, a longa tradição de culto a Maria sob a invocação de Nossa Senhora da Conceição em terras luso-brasileira e, em particular, em Pernambuco.

O mesmo podemos ver nos cordéis que trazem disputas entre católicos e protestantes, ponto que passamos a abordar. Um dos cordéis já analisado, $O$ debate do ministro nova-seita com o urubu, da autoria de Leandro Gomes de Barros ${ }^{23}$, trata da morte de uma neófita, dando início a um debate entre um urubu e um pastor protestante, nos seguintes termos, pelos quais o urubu pergunta ao pastor protestante:

E porque a nova-seita

Detesta Nossa Senhora?

Sendo mais clara que o dia,

Sendo mais pura que a aurora?

O nova-seita morrendo,

Não vê o céo nem por fôra.

Eu sou urubú, mas creio,

Juro por fé e verdade,

Que Maria nasceu pura,

E faz parte da divindade,

Deu a luz a Jesus Christo,

Conservando a virgindade.

\footnotetext{
${ }^{22}$ MEGALE, Nilza Botelho. 107 Invocações da Virgem Maria no Brasil: História, folclore e iconografia. Petrópolis: Vozes, 1980, p. 13, p. 112-113.

${ }^{23}$ In: BARROSO, Ao som da viola, p. 506-513.
} 
Então, disse o nova-seita:

Eu creio em meu Salvador,

Pois foi quem morreu por mim,

Foi elle o meu redemptor.

Perguntou-lhe o urubú:

Não teve mãe o senhor?

Maria não ficou virgem

Depois do Senhor nascer?

Não foi o Espírito-Santo

Que fez ella conceber?

E porque a nova-seita,

Crê num e no outro não crê?

Nestas estrofes, percebemos que o que mais incomoda ao urubu é a negação pelos "nova-seitas" dos dogmas católicos, a exemplo da imaculabilidade de Maria e do seu culto. Foi o papa Pio IX o proclamador do dogma da Imaculada Conceição, como podemos ver em um trecho da encíclica Ineffabilis Deus de 1854:

Portanto, após ter diligente considerado todas as coisas e ter elevado assíduas e fervorosas orações a Deus, avaliamos ter chegado a hora de sancionar e definir com o nosso supremo juízo a imaculada conceição da Virgem; e assim satisfazer os piíssimos desejos do mundo católico, a nossa devoção em relação à Santíssima Virgem, e, igualmente, honrar sempre mais nela seu Filho unigênito, nosso Senhor Jesus Cristo; pois todos estão convencidos de que toda a honra e glória que se tributa à Mãe alcança o filho. ${ }^{24}$

Ambos os aspectos estão efetivamente presentes nas denominações protestantes, visto que estas só acreditam na virgindade de Maria em relação à concepção de Jesus, sendo mãe de outros filhos de seu casamento com José. Igualmente, negam o poder intercessor de Maria junto a Deus. Ao ver negada tal crença dos católicos, o urubu julga esta característica como um dos grandes deméritos da fé reformada. De fato, não só é bem sabido que a recusa do culto à Maria é um dos aspectos da fé cristã reformada presente em todas as denominações, como se sabe da forte presença do culto mariano na religiosidade católica do Brasil em geral e, igualmente, no Nordeste.

A contenda sobre a figura de Maria aparece em alguns cordéis de Leandro Gomes de Barros. No cordel $O$ diabo na nova-seita ${ }^{25}$ este aspecto também está presente. $\mathrm{O}$ folheto narra que, após ficar pobre, um filho do diabo decide entrar ou na nova-seita

${ }^{24}$ COSTA, Lourenço. (org.). Documentos da Igreja: documentos de Gregório XVI e Pio IX. São Paulo: Paulus, 1999, p. 184.

${ }^{25}$ BARROS, L. G. de. O diabo na nova-seita. Instituto de Estudos Brasileiros - IEB/USP: Fundo Villa Lobos, $n^{\circ} 09$. 
ou para o catimbó, referências ao protestantismo $e$ aos cultos afro-brasileiros no Nordeste. O diabo-pai, no entanto, adverte-o que ambas seriam más escolhas. Sem dar ouvidos ao pai, o diabo filho convida alguns animais a participar da nova-seita com ele. As estrofes seguintes narram o mal que aconteceu aos animais que já haviam freqüentado o culto dos nova-seitas. Por fim, convencido do mal que seria aderir à nova-seita, conclui o diabo filho:
O que você está dizendo
É uma pura verdade
Essa raça nova-seita
Abusa da divindade,
Crê no filho e nega a mãe,
Como é essa novidade? ${ }^{26}$

Uma vez mais, é a negação do culto à Maria uma característica central na figuração dos protestantes, negação esta apontada como o aspecto que denota a ilegitimidade das "seitas" protestantes, pois os autores não concebiam o cristianismo centrado apenas no culto à figura de Jesus. Vejamos, ainda, outro cordel, no qual a recusa ao culto mariano ganha relevo. O folheto chama-se $O$ diabo confessando um nova-seita ${ }^{27}$.

Só serão estes os pecados?

Interroga, o negro então:

Disse o nova seita sim...

Uma vez no sermão,

Estava vexado e chamei, a virgem da Conceição!

O negro se ergueu e disse:

Diga os nomes que quiser;

Faça por não se lembrar,

Do nome dessa mulher,

Eu passo mil léguas longe,

Do lugar que ela estiver.

Note-se, no que se refere à Maria, que aquilo que é um preceito na fé católica é apresentado, inversamente, como um pecado na concepção protestante, o que denota conhecimento da mesma, dado que os cristãos reformados invocam apenas a Jesus, como mediador entre os indivíduos e Deus Pai.

A importância central da afirmação pelos católicos e da negação pelos protestantes dos dogmas marianos é um elemento presente desde a Reforma protestante e que se

\footnotetext{
${ }^{26}$ BARROS, O diabo na nova-seita, p. 05.

${ }^{27}$ In: LITERATURA Popular em Verso. Antologia, tomo V. Leandro Gomes de Barros - 3. Rio de Janeiro: Ministério da Educação e Cultura, Fundação Casa de Rui Barbosa; João Pessoa: Universidade Federal da Paraíba, 1980, p. 58-64.
} 
mantém como um divisor entre cristãos católicos e os reformados, até os nossos dias. A característica mais óbvia - diz-nos Jaroslav Pelikan — da posição que Maria ocupou na Reforma protestante foi a crítica e a rejeição daquilo que fora considerado como devoção e ensinamento medievais excessivos ${ }^{28}$. Na forma em que aparece nos cordéis aludidos, percebe-se a relevância deste aspecto na perspectiva dos cordelistas acerca da prédica protestante.

Ressalte-se, porém, que este poeta, ao defender os dogmas marianos, não tem em vista a defesa da religião católica enquanto instituição. Voltemos ao cordel intitulado Debate entre o ministro nova-seita com o urubu: nele, a figura que representa o padre é a do urubu, devido à indumentária de cor preta usada pelos clérigos seculares; tal alegoria denota a ironia em relação à hierarquia oficial da Igreja Católica, à qual o autor devotava aguda ojeriza ${ }^{29}$.

Vale destacar a utilização da figura do urubu como o defensor do catolicismo. O urubu é uma ave agoureira e pouco simpática no folclore, egoísta, orgulhosa, solitária, esperta, astuta e raramente enganada ${ }^{30}$. O uso do urubu como representante do catolicismo no debate nos revela uma das características da obra de Leandro G. de Barros que era o anticlericarismo, apesar de ser católico, o autor criticava a postura desmoralizada de alguns padres.

\section{Imagens de madeira: a questão da iconoclastia}

Entre as práticas religiosas, de tradição católica, rejeitadas pelos protestantes desde o princípio da cisão entre estas duas vertentes do cristianismo, encontra-se o culto dado aos santos representados em imagens. Como assinala o historiador Pelikan, o contexto da crítica da Reforma era fundamentalmente uma reconsideração sobre a prática de cultuar os santos. A questão foi exposta e debatida por Ulrich Zwingli, Filipi Melanchthon (discípulo de Lutero) e Calvino, para citar os principais ${ }^{31}$.

Os iconoclastas logo nos primeiros anos da Reforma se preocuparam em tirar as imagens das igrejas, onde em muitos casos a população destruía qualquer representação dos santos, das imagens de madeira e até mesmo os afrescos não foram poupados. A questão do iconoclastismo se espalhou pelos países protestantes da Europa, como na Suíça, Holanda e Escócia. Dreher nos informa que o grande mentor do iconoclasmo foi Andreas de Karlstadt, que publicou um livro cujo título era Da eliminação de imagens ${ }^{32}$.

Veremos em seguida como este aspecto da divergência entre católicos $e$ reformados revela-se central na perspectiva da literatura de cordel acerca dos protestantes. Num dos folhetos que apresentamos, percebe-se que o poeta já ouvira

\footnotetext{
${ }^{28}$ PELIKAN, Maria através dos séculos, p. 208.

${ }^{29}$ MAYA, Ivone. In: WERNECK, Alexandre, "Os donos da voz", Nexo - Revista da FAPERJ. Rio de Janeiro, n. 31, set. 2003, p. 04.

${ }^{30}$ CASCUDO, Luís da Câmara. Dicionário do Folclore Brasileiro - Vol. 2. Ed. Rev. São Paulo: Global, 2002, p. 762.

${ }^{31}$ PELIKAN, Maria através dos séculos, p. 209-10.

32 DREHER, Martin. A crise e a renovação da igreja no período da Reforma. São Leopoldo: Sinodal, 1996, p. 53-54.
} 
dos protestantes falar em alcançarem salvação certa por serem "nova-seita", na contestação dos dogmas católicos e de suas práticas pelos devotos.

Isso não! disse o ministro.

Eu hei de seguir Jesus,

Porque foi quem me salvou,

É meu guia e minha luz.

Perguntou-lhe o urubú:

Porque tem raiva da cruz?

Não foi nella que morreu

Nosso Senhor Jesus Christo?

$O$ sangue que derramou

Você na cruz não tem visto?

Você só tem é abuso,

Convêm acabar com isto. ${ }^{33}$

O urubu cobra-lhe por não aceitar as imagens consideradas sagradas pelos católicos; por outro lado, a recusa de imagens nos cultos reformados não é um aspecto presente em todas as denominações reformadas. Assim, o questionamento pelo autor da aversão dos "nova-seita" à cruz faz pensar que ele refere-se a uma ou algumas determinadas denominações que mantinham missionários na região, provavelmente os batistas, e que delas deve ter ouvido este ponto ou visto seus templos desprovidos daquela e de quaisquer outras imagens.

Para a nossa compreensão sobre a defesa da cruz, por parte do cordelista, é enriquecedor o comentário de Riolando Azzi sobre o catolicismo popular brasileiro. Azzi diferencia o sentido do uso da cruz para a dita religião oficial e para a chamada devoção popular ao afirmar que:

A cruz como marco de conquista, como local de culto litúrgico são expressão da religião oficial. Persignar-se tornouse um hábito familiar aos brasileiros: ao passar diante de um oratório, de uma igreja, de um enterro, de uma tumba, as pessoas geralmente fazem o sinal da cruz. Como o fazem também com freqüência os banhistas antes de entrar no mar como expressão da devoção popular. ${ }^{34}$

Afirma-se, assim, o valor devocional que as camadas populares, ou os leigos católicos em geral, atribuem à cruz, o que torna o tema sensível à abordagem protestante do uso de imagens e, desta forma, bastante presente na caracterização dos reformados pelos cordelistas.

As discordâncias entre católicos e protestantes acerca do uso de imagens, como se sabe, não se resume à figura da cruz. As três estrofes que reproduzimos abaixo, do

\footnotetext{
${ }^{33}$ In: BARROSO, Ao som da viola, p. 508-9.

${ }^{34}$ AZZI, Riolando. O catolicismo popular no Brasil: aspectos históricos. Petrópolis: Vozes, 1978, p. 13-21. 
cordel o Debate do ministro nova-seita e o urubu, nos dão uma idéia de como esta divergência se desdobra e foi percebida pelos cordelistas:

Então, disse o nova-seita:

$O$ diabo te persiga.

Disse o urubú: a ti!

Nova-seita, dou-te figa,

$\mathrm{Tu}$, onde vais, deixas rastro,

De fome, peste e intriga.

Eu, sendo um bruto pagão,

Observo os mandamentos,

E tu, sendo batizado,

Negas os ensinamentos,

corres como um cão danado,

Se se fala em sacramento.

Um santo estava ali perto

E o diabo também.

Bravos! O santo dizia,

Este urubu fala bem,

Morra aos berros o nova-seita!

Dizia o diabo: amém! ${ }^{35}$

O fim da peleja (pois não deixa de ser neste estilo que o urubu e o nova-seita se confrontam), é bem significativo, trazendo elementos católicos caros aos seus fiéis para condenar o nova-seita e valorizar a "vitória" do urubu. Quem dá o aval final é um santo, mais um elemento do catolicismo negado pelos reformados; e, para que não reste dúvida sobre quem está certo, diz o próprio diabo: "Amém!".

Numa das estrofes da Segunda peleja do capitão protestante com João Melchiades no novo testamento sendo a nova seita vencido pelo Catholico em todos seus argumentos a polêmica em torno do uso de imagens pelos católicos é, também, relevante. Pela pena de Melchiades, o protestante diz ao poeta:

Mas vocês inda não tem

A fé pura e verdadeira

Por que vão fazer promessas

A imagem de madeira

Santo de pau não é nada

Roma tem esta besteira. ${ }^{36}$

\footnotetext{
${ }^{35}$ In: BARROSO, Ao som da viola, p. 512-513.

36 Apud: CANTEL, Raymond. "As querelas entre protestantes e católicos na literatura popular no nordeste brasileiro". In: 1972, p. 67. . Temas da atualidade na literatura de cordel. São Paulo: USP/ ECA,
} 
Uma das características centrais concernentes ao catolicismo popular, no que se refere as manifestações de fé, é a relação entre o fiel e o seu santo de devoção. Esta ligação traz a marca da pessoalidade, do contato direto entre o devoto $e$ o santo, não apenas representado, mas personificado em imagens. Observam-se duas formas pelas quais se dá tal relação entre os fiéis e os devotos, ou melhor, entre um fiel e seu santo de devoção, o que se chama de a "privatização" do catolicismo ${ }^{37}$.

A relação "devocional" caracteriza-se pela fidelidade do devoto ao santo, que é tido em conta de "padrinho celestial". Trata-se, todavia, de uma relação de reciprocidade: o devoto deve prestar um culto ao seu santo de devoção de modo regular. O santo, por sua vez, deve proteger seu devoto nesta vida e facilitar seu acesso à vida eterna ${ }^{38}$.

A segunda modalidade de relação, embora também pessoal, é menos rígida que aquela outra. Trata-se da relação "contratual", que põe o devoto e o santo em relação visando a uma graça específica requerida pelo primeiro. Por meio do "contrato" o fiel se obriga a cumprir uma promessa feita ao santo, que deve conceder a graça antes. Esta ordem também pode ser invertida, sendo o fiel a executar a "paga", como uma novena, pela qual o santo torna-se "devedor" do fiel. O caráter provisório desta relação específica revela-se pelo que se segue ao contrato cumprido: mas desde que as duas partes contratantes estejam quites, o contrato está terminado, podendo a relação ser desfeita: o fiel não tem mais qualquer obrigação para com o santo ao qual recorreu ${ }^{39}$.

Seja por qualquer uma destas formas em que se efetive a devoção católica dita popular, voltada para o culto dos santos e santas (mesmo os que não são canônicos), revela-se a importância destes nesta vertente do catolicismo. O caráter pessoal desta relação que acabamos de expor faz do santo e da santa de cada devoto um ente próximo ao qual se pode recorrer direta e concretamente. Os santos e santas são, portanto, parte indelével da fé católica, dita popular, por fazerem parte da experiência cotidiana dos fiéis.

De acordo com a análise freyreana, esta forma de catolicismo "doméstico" é constitutiva mesmo da formação social brasileira, estando presente nas relações interpessoais e refletindo-se na relação "familiar" entre os devotos e os santos ${ }^{40}$. Ao contrário da Europa pós-Trento e da América hispânica, na América portuguesa teria vingado um catolicismo mais maleável, "doce", "lírico e festivo". Em lugar do predomínio da religiosidade no âmbito das igrejas, o catolicismo do Brasil colonial vicejou dentro das casas, sob a autoridade patriarcal dos senhores de terras e homens.

${ }^{37}$ OLIVEIRA, Pedro A.; VALLE, Edênio \& ANTONIAZZI, Alberto. Evangelização e comportamento religioso popular. Petrópolis: Vozes, 1978, p. 28.

${ }^{38}$ OLIVEIRA, VALLE \& ANTONIAZZI, Evangelização e comportamento..., p. 29.

${ }^{39}$ OLIVEIRA, VALLE \& ANTONIAZZI, Evangelização e comportamento..., citações nas p. 30-31.

${ }^{40}$ FREYRE, Gilberto. Casa Grande \& Senzala. 12. ed. Brasília: Editora da UnB, 1963, p. 15, p. 86. Notemos, de passagem, que essa marca do catolicismo só se cingiu ao âmbito popular no período republicano, pois, até o império, era um traço devocional da maioria dos católicos brasileiros. Veja-se, por exemplo, a personagem machadiana Flora, em Esaú e Jacó, que reza para o seu Jesus particular, de marfim, que mantém no quarto, crendo que a intimidade com ele o faz mais solícito a suas orações. ASSIS, Machado de. Esaú e Jacó. São Paulo: Martin Claret, 2003, 174-175. 
Esse catolicismo "doméstico" manifestava-se na relação com os "santos compadres, [e] santas comadres dos homens, [com] Nossas Senhoras madrinhas dos meninos" 41 .

Os cordéis dos quais nos utilizamos permitem-nos lançar algumas suposições. Uma dela é a de que os cordelistas mostram diferente grau de conhecimento quanto aos preceitos dos cristãos reformados, como, por exemplo, a querela em torno da imagem da cruz evidencia que alguns deles devem ter tido contato com denominações de protestantes similares (relembremos que nem todas rejeitavam o símbolo da cruz), como a dos batistas. O que efetivamente é rejeitado por todos os protestantes é a representação de Cristo na cruz, ou seja, o crucifixo, enquanto algumas denominações, como os presbiterianos, apresentam cruzes em seus templos, embora vazias, isto é, sem a imagem de Cristo crucificado.

\section{A descrição pejorativa do protestante}

Além das questões dogmáticas abordadas pelos cordelistas, ressaltam as hostilidades à figura dos reformados, que se manifestavam das mais variadas formas, dentre elas, apelidos e cantigas. Assim sendo, analisando a presença dos protestantes segundo a perspectiva da literatura de cordel, percebemos a grande frequência com que esses são caracterizados de forma negativa. Esta caracterização pode ater-se a aspectos meramente físicos ou de caráter moral, tanto em cordéis em que a temática protestante é central, quanto naqueles em que o nova-seita é uma figura secundária, citada de passagem. Essa ridicularização da figura do protestante, denotando o embate entre este e os católicos, foi percebida por um dos grandes estudiosos da dita cultura popular nordestina.

No cordel $O$ diabo na nova-seita, do qual já fornecemos um resumo acima, um filho do diabo deseja aderir ao protestantismo, sem dar ouvidos ao pai, que o desaconselha, dizendo que, se ele entrasse para a nova-seita, seria expulso do inferno. Para dissuadi-lo, o diabo passa a fazer perguntas aos animais que já haviam se convertido à nova-seita. Quem primeiro fala é o diabo-pai, de quem citamos outra fala no final, tendo de entremeio a advertência do sapo:

O nova-seita já nasce

Triste, amarello e sem cor,

A vista sempre espantada

Com aspecto aterrador,

Sem alma e sem conciencia,

Sem prazer e sem amor.

${ }^{41}$ FREYRE, Casa Grande \& Senzala, p. 396.

SAECULUM - Revista de História [36]; João Pessoa, jan./jun. 2017. 
O sapo disse eu tambem

Era animal assiado

Tinha um corpo tão bonito!

O cabello cachiado

O nova-seita illudiu-me

Olhe como estou pellado.

O diabo disse a elle:

Você é meu enteado,

Tem todos os signaes ruins

Feio, magro e descorado,

Foi entrar na nova-seita

Já anda até assustado. ${ }^{42}$

Igualmente, no cordel A confissão de Antônio Silvino, em que o famoso cangaceiro tenta se confessar com um padre, para ver se era possível obter o perdão divino, mas, devido às respostas que recebe do pároco, ambos acabam entrando em luta corporal, o tom pejorativo é semelhante, como se pode ver na seguinte estrofe:

Antônio Silvino disse:

Pois vamos ver, padre-mestre!

Custoso é ver sogra boa

E nova-seita que preste.

Bode por gosto lavar-se,

Jumento no mar criar-se,

Nascer baleia no agreste! ${ }^{43}$

Mais uma vez, no folheto $O$ diabo confessando um nova-seita apresenta teor tal qual dos demais, o que se pode confirmar pelas duas estrofes abaixo:

Bem no tronco da jurema,

Estava um velho ajoelhado;

Esse era um nova seita,

Muito amarello e barbado;

Desses que trazem ao nascer,

Diploma de desgraçado.

${ }^{42}$ BARROS, Leandro Gomes de. O diabo na nova-seita. Instituto de Estudos Brasileiros - IEB/USP: Fundo Villa Lobos, $\mathrm{n}^{\circ} 09$.

${ }^{43}$ BARROS, Leandro Gomes. A confissão de Antônio Silvino. São Paulo: Luzeiro, 1980, p. 08. 
Um desses que vem ao mundo

Fazer semente de tinha

Que só teve por herança

A sorte ingrata e mesquinha;

Trata a crise por mamãe;

Chama a desgraça madrinha. ${ }^{44}$

Em A Alma de uma Sogra, do qual já citamos uma estrofe, das cinco sogras descritas de um velho tabelião, a pior delas foi a última, que, ainda depois de morta, perturbou o genro. O segredo de suas maldades é desvelado na última estrofes:

A cobra era nova seita

Eu conheci o mysterio

E eu pude conhecer

Que o acto não era serio,

Tanto que eu disse logo,

Desgraçou-se o cemiterio. ${ }^{45}$

Poderíamos multiplicar aqui as citações, embora encontremos esta característica apenas na obra de Leandro Gomes de Barros, de cuja autoria saíram os trechos acima citados. Neles podemos perceber dois tipos, ao menos, de descrição de teor negativo: uma meramente física, pela qual o protestante pode ser visto como feio, magro e descorado ou amarello e barbado e, ainda, a descrição negativa do caráter do protestante, como no cordel que Antonio Silvino afirma que não há nova-seita que preste.

Assinalamos, ainda, este aspecto na seguinte estrofe do cordel Debate do ministro nova-seita com um urubu:

Perguntou o urubu:

De onde veio esta derrota?

Empestar o nosso campo,

Com essa enorme marmota?! ${ }^{46}$

No primeiro diálogo entre o urubu e o ministro protestante, diante da afirmação deste que a "nova-seita" era uma devota, o urubu surpreende-se, como se ouvisse e visse uma novidade: de onde veio esta derrota [...] Com essa enorme marmota? No dizer popular da região Nordeste, marmota é indivíduo mal vestido, espantalho ${ }^{47}$.

Outra forma de descrição em demérito dos protestantes consiste no apelido de bode. Encontramos na bibliografia a respeito três explicações sobre a origem do termo empregado para denominar os protestantes no Nordeste. Uma delas provém

\footnotetext{
${ }^{44}$ In: LITERATURA Popular em Verso, p. 59.

${ }^{45}$ BARROS, Leandro Gomes de. A alma de uma sogra. S.l.: s.n., 19-, p. 8.

${ }^{46}$ In: BARROSO, Ao som da viola, p. 507.

${ }^{47}$ ALMEIDA, Horácio de. Dicionário popular paraibano. João Pessoa: Ed. Universitária/ UFPB, 1979, p. 111.
} 
do missionário congregacional M'Call, que explicou a origem da expressão de zombaria: Acontece que eu tenho uma barba grande e bem loira, algo raro no Brazil, e me chamam de Frei Bode ${ }^{48}$.

Por sua vez, o historiador Émile Leonard fornece outra possível origem para o apelido jocoso, o qual se originou da barbicha do Rev. Smith, presbiteriano, que, em 1874, tentou uma obra de evangelização em Maceió, e que, realmente, usava "cavagnac" 49.

A expressão bode é muito utilizada na fala nordestina, como bem lembrou Mauro Mota. De bode classifica-se o homem mulherengo, o valete de baralho, o nova-seita, o almoço de trabalhador rural que é servido no campo, a alteração, a encrenca.Também são denominados de bode preto os maçons, o indivíduo afônico, de bode rouco. Ainda é dito de quem se comporta mal, de quem se mete em aventuras e bagunças, que pinta o bode; e de um trabalho bem feito, se diz: certo que só beiço de bode; e sem vergonha que só bode criado em casa, diz-se de pessoa sem contenção e pudor; quem menos pode é quem paga o bode, sobre as dificuldades dos mais fracos. O caprino surge ainda em defesa do bigode: homem tem bigode, quem tem cavanhaque é bode. Podemos, por fim, mencionar a advertência popular: "prendam suas cabras que os bodes andam soltos" 50 .

Câmara Cascudo também comenta o uso e os sentidos da palavra bode para os nordestinos, ao informar que:

O bode preto era a forma clássica do Diabo nas festas dos sabats. É um dos animais, o mais típico, para os processos feiticeiros da transferência simbólica de moléstias venéreas. Qualquer bruxa velha de outrora, sabedora de orações $e$ remédios fortes, informava do poder do bode, sinônimo diabólico, temido e respeitado na ambivalência natural. ${ }^{51}$

Para finalizar, também podemos mencionar mais um possível elemento para o uso do apelido de bode dado aos cristãos reformados, ou seja, o uso da palavra inglesa brother. Possivelmente essa palavra era utilizada pelos missionários norte-americanos, para se referirem uns aos outros, pois, como se sabe, os protestantes costumam se chamarem de irmãos.

Sabedores da importância do uso difundido do termo "bode" na fala nordestina $e$ das possíveis origens do apelido de bode para denominar os protestantes, fica mais compreensível sua ocorrência nos cordéis que tem o protestante por tema, uma vez que, além do uso da barba pelos missionários, aparece em vários cordéis a referência ao protestantismo como coisa do diabo. Como nas estrofes abaixo, a primeira do folheto $O$ diabo confessando um nova-seita e a segunda retirada de $O$ azar e a feiticeira. No primeiro cordel lemos:

${ }^{48}$ EVERY-CLAYTON, Joyce E. W. Um grão de mostarda... documentando os inícios da Igreja Evangélica Pernambucana, 1873-1998. Recife: Igreja Evangélica Pernambucana, 1998, p. 64.

${ }^{49}$ LEONARD, Émile G. O protestantismo brasileiro. 3. ed. São Paulo: ASTE, p. 121, nota 16.

${ }^{50}$ MOTA, Mauro. "O bode no Nordeste". In: SOUTO MAIOR, Mário \& VALENTE, Waldemar (orgs.). Antologia pernambucana de folclore. Recife: FUNDAJ; Massangana, 1988, p. 203-206.

${ }^{51}$ CASCUDO, Luis da Câmara. Coisas que o povo diz. Rio de Janeiro: Bloch, 1968, p. 78-80. 
Pois bem retorquio o negro:

Se quizer ficar commigo,

Não afrocha a nova seita,

Tenha Deus como inimigo,

Faça o que frei bôdefaz,

Contra si não ha perigo. ${ }^{52}$

E no segundo:
A velha exclamou: Meu Deus!
Viver assim niguem pode
Boto a desgraça de um lado
Do outro a miseria acode
Este diabo é ovelha
Da criação de frei bode. ${ }^{53}$

O mau aspecto físico também se combina com a desdita moral, como o nova-seita que, além de amarello e barbado, tem por herança a sorte ingrata e mesquinha. Vejamos outra estrofe, na qual podemos ver um aspecto "moral" pejorativamente relacionado ao protestante. $\mathrm{O}$ cordel versa sobre a feiticeira às voltas com o azar; como indica o título, não é um protestante que é representado, mas o azar. A velha recebe em sua casa um passante, sem saber quem ele é de fato. Depois de acolhê-lo, sucedem-se uma série de acidentes domésticos. Ela então indaga quem é o seu hóspede, que se revela ser o Azar. Eis, então, como ela reconhece a procedência do mesmo:
A velha em tudo mostrou-se
Que estava mal satisfeita
Disse ao azar: nessa casa
Você nunca mais se deita.
Vio no bolso do azar,
Um livro da nova seita.

A relação entre o Azar e os protestantes é indicada pela posse do "livro da nova seita", o que remete a um dos aspectos desta caracterização, que já abordamos. Noutra estrofe, as desditas relacionadas ao azar se sucedem:

\footnotetext{
${ }^{52}$ In: LITERATURA Popular em Verso, p. 62.

${ }^{53}$ BARROS, Leandro Gomes de. O azar e a feiticeira, p. 03. Instituto de Estudos Brasileiros - IEB/USP: Coleção Leandro Gomes de Barros, $n^{\circ} 08$.
} 
Foi ela acudir a roupa

E caio numa cisterna

Saiu e com um pouco mais

Desconjuntou uma perna

Murmurou ela consigo:

Esta caipora é moderna. ${ }^{54}$

Nesta sextilha uma palavra específica denota a depreciação do nova-seita: caipora. O termo, de uso comum na linguagem popular do Nordeste, refere-se a um gênio malfasejo da mithologia dos índios brasilienses, de máu agouro encontrá-lo, e dahi chamar-se caipora, a quem tudo vai ao revez ${ }^{55}$, uma vez que a caipora tem os pés voltados para trás.

Ainda sobre a descrição pejorativa do protestante, outro ponto já nos é mencionado por Raymond Cantel, quando afirma que numa posição extremista ele [o cordelista] o verá como enviado do Diabo ${ }^{56}$. No já citado cordel $O$ diabo confessando um nova-seita, podemos constatar o que acima foi afirmado, pelas seguintes estrofes:

Espero que ás de ser sempre

Muito fiel a nova-seita,

No inferno onde eu habito

Tua cama já está feita,

Ficará lá no inferno

Tua alma a minha direita.

Disse o velho que contou-me,

Só pude aturar uma hora.

Agora sim, posso crer,

Que o nova seita é caipora,

É quasi um filho bastardo,

Que o diabo cria fôra.

E o que esse velho diz

É uma pura verdade,

Aonde ha nova seita,

A pouca prosperidade

Aquillo foi um castigo,

Que veio da eternidade.

\footnotetext{
${ }^{54}$ Ibidem, p. 02.

${ }^{55}$ COSTA, F. A. Pereira da. Vocabulário pernambucano. 2. ed. Recife: Secretaria de Educação e Cultura, 1976, p. 160, grifo do autor.

${ }^{56}$ CANTEL, "As querelas entre protestantes...", p. 68.
} 
Foi o diabo com raiva

Que tomou essa dispeita,

Tomando inveja de Deus

Fez essa infernal receita,

Despachou-a no inferno

Fez com ella a nova seita. ${ }^{57}$

Em outro cordel, o qual já citamos, intitulado $O$ diabo na nova-seita, do mesmo autor, podemos ver mais uma vez o protestantismo ser identificado como uma obra do diabo.

Disse o diabo meu pai,

Foi quem plantou essa raça.

Disse o velho eu não pensei

Que saísse tal desgraça

Para deixar a caipora

Por todo lugar que passa.

Neste caso, o próprio diabo se surpreende e reprova sua obra, ou seja, o novaseita é pior que o diabo. A associação entre a fé reformada e o diabo denota a recusa pelo autor em considerar o protestantismo como um dos cultos legítimos entre os cristãos.

$\mathrm{Na}$ análise das querelas entre católicos e protestantes nos cordéis, Raymond Cantel resume a representação construída pelos cordelistas sobre a figura do protestante. Diz o autor que:

Os cordelistas se apegam às diferenças mais evidentes [...]. Eles conceberam o retrato de um protestante típico. [...]. O protestante é mais ou menos idêntico em todo o vasto Nordeste, com sua Bíblia, sua instrução, seu ar sério, sua ausência de humor, sua tendência ao proselitismo. ${ }^{58}$

É esclarecedora, igualmente, a afirmação de Mark Curran sobre o que ele chama de cosmovisão dos cordelistas da primeira geração. Segundo o autor, tal cosmovisão se constitui por sistemas de valores religiosos e sociais

[...] De inspiração religiosa, baseado sobretudo no catolicismo tradicional, o sistema social marcado pela estrutura de classes do Brasil colonial e o meio cultural do povo humilde contribuíram para formar a cosmovisão tão evidente nas obras do cordel antigo. ${ }^{59}$

\footnotetext{
${ }^{57}$ In: LITERATURA Popular em Verso, p. 63-64.

${ }^{58}$ CANTEL, "As querelas entre protestantes...", p. 68.

${ }^{59}$ CURRAN, Mark. História do Brasil em cordel. 2. ed. São Paulo: EDUSP, 2001, p. 48.
} 
Este "protestante típico" é, portanto, contrastado com as tradições católicas do Nordeste do Brasil, evidenciando-se aquilo que ele apresenta de estranho à cultura em que se formou o cordel. Assim, destaca-se a associação permanente entre os protestantes e seu apego à (sua versão da) Bỉblia, a negação do culto à Maria, a rejeição de imagens (os santos, o crucifixo) e, em consonância com o caráter jocoso dos folhetos, faz parte desta caracterização a descrição pejorativa dos aspectos físicos do protestante.

\section{$\operatorname{soc}$}

\section{RESUMO}

$\mathrm{O}$ artigo aborda a produção de cordel de dois autores da primeira geração de cordelistas, Leandro Gomes de Barros e João Melchiades Ferreira da Silva, entre as décadas de 1890 e 1930, cujos folhetos traziam como tema, entre outros assuntos, discussões entre católicos $e$ protestantes. Os estudos que trataram da penetração protestante no Brasil, do início do Oitocentos à primeira metade do séc. XX, ainda não contemplaram o uso dos cordéis como fontes históricas, que nos permitem uma aproximação da perspectiva, em parte, popular do contato com formas de religiosidade que eram novas para a sociedade brasileira. Pela análise dos folhetos, percebemos uma caracterização específica dos protestantes feita pelos cordelistas, os quais destacavam a rejeição do culto a Maria, aos santos, o uso de imagens (a crucifixo), a polêmica em torno da posse e leitura da Bíblia protestante e a descrição pejorativa dos protestantes.

Palavras Chave: Cordel; Protestantismo; Catolicismo.

Artigo recebido em 06 mar. 2016.

Aprovado em 22 ago. 2016.

\begin{abstract}
The paper treats on the production of the chapbooks of two authors of the first Brazilian "cordelistas" generation, Leandro Gomes de Barros and João Melchiades Ferreira da Silva, between the 1890s and 1930s, whose pamphlets included topics such as discussions between Catholics and Protestants. The studies dealing with Protestant penetration in Brazil, from the beginning of the 19th century to the first half of the 19th century, XX, have not yet contemplated the use of cords as historical sources, which allow us to approach the perspective, in part, of popular contact with forms of religiosity that were new to Brazilian society. Through the analysis of the leaflets, we noticed a specific characterization of Protestants by the cordelistas, who emphasized the rejection of the cult of Mary, the saints, the use of images (the crucifix), the controversy surrounding the possession and reading of the Protestant Bible, and pejorative description of Protestants.
\end{abstract}

Keywords: Chap Book; Protestantism; Catholicism. 